J. Japan. Soc. Hort. Sci. 45(3):275-282. 1976.

\title{
The Role of Cotyledons in Growth and Photosynthesis of Radish Plants
}

\author{
Shigetoshi Suzukr* \\ Faculty of Agriculture, Nagoya University, Chikusa, Nagoya
}

\begin{abstract}
Summary
When cotyledons of radish plants were excised at an early stage of growth, decrease in plant growth was observed. To understand this phenomenon, the role of cotyledons in radish growth was examined.

Dry weight of cotyledons decreased and that of the other organs increased in the dark, whereas dry weight of every organ increased in the light. Furthermore, dry weight of hypocotyls and that of roots decreased in decotylized plants grown in the light, but decrease in dry weight of foliage leaves was not observed. From these results, it was concluded that cotyledons were the source and the other organs were the sink. Especially, the foliage leaves could be regarded as the strongest sink.

In Rapid Red cultivar, the growth phase could be divided into two periods (Phase 1 and Phase 2). In Phase 1, the growth of foliage leaves was enhanced by the supply of reserve materials and photosynthetic products from cotyledons. In Phase 2, activet hickening growth of hypocotyls was caused by a sufficient supply of photosynthetic products from foliage leaves. Therefore, it is concluded that the decrease in radish growth by decotylization is due to the resulting decrease in the growth of foliage leaves.
\end{abstract}

\section{Introduction}

The cotyledon is the first leafy organ in the ontogenesis of higher plants and so has a function similar to that of foliage leaves. In several species of plants, the role of cotyledons has been studied in relation to dwarfism (4), flowering $(9,10)$, phototropism(12), stem elongation $(1,6,7,16)$, and root nodule formation(17). It has become evident that cotyledons play important roles in the regulation of growth or differentiation phenomena as well as in the supply of nutritional materials. It is a well known fact that an injury to cotyledons in the early stage of growth of crops causes reduction in growth and in final yield. For this reason, plants whose cotyledons remain healthy are selected by a grower when seedlings are thinned or transplanted. Thus, an estimation of the role of cotyledons in crop growth becomes an important problem.

FRIES(2) reported the results of experiments

* Present adress : Faculty of Agriculture, Meijo University, Tenpaku, Nagoya.

Received for publication October 27, 1975. on the growth of decotylized pea seedlings. However, the growth correlation between cotyledons and under-ground organs has not been studied in detail. In radish plants, the auther observed that a marked decrease in final yield of thickened organs was caused by decotylization in the early stage of growth. Although thickening growth of radishes is caused by an active xylem differentiation(5) and it is expected that a system of regulation by hormone-like substances may be involved in that phenomenon, in this paper, the growth correlation between cotyledons and thickened organs was reported by examining the role of cotyledons in functioning as a reserve organ and as a photosynthetic organ.

\section{Materials and Methods}

\section{Field experiment}

The effect of decotylization in the early stage of radish growth on final yield was studied in a field scale experiment. The seeds of Raphanus sativus L. cv. Risô Daikon were sown directly in the experimental field of the Horticultural Laboratory of Nagoya 
University on Sept. 11 in 1973. One or two cotyledons of 10-day-old and 20-day-old plants were excised and the effect of decotylization on final yield was estimated by measuring the fresh weight of thickened organs and foliage organs of the plants on Nov.29. Results were expressed as the mean value of one hundred plants.

2. The effect of decotylization on the growth of radish seedlings (cv. Risô Daikon)

The seeds were sterilized with $0.1 \%$ Uspulun for $30 \mathrm{~min}$. After they were washed in tap water for $2 \mathrm{hr}$, they were germinated on wet filter paper in the dark at $25^{\circ} \mathrm{C}$ for $48 \mathrm{hr}$. The germinated seeds were selected for uniformity and were planted in a pot with vermiculite. For 12 days, plants were grown under continuous light at $20-25^{\circ} \mathrm{C}$. The cotyledons were excised on the 4 th, $7 \mathrm{th}$, and 10 th days after germination and change in the dry weight of each organ was measured. In addition to the above experiment, the growth of seedlings grown in the dark at $25^{\circ} \mathrm{C}$ was measured for 6 days after germination.

3. Experiment in cv. Rapid Red

After the seeds were germinated under the same conditions as described in Experiment 2 and selected for uniformity, the plants were grown in the phytotoron where temperature was controlled at $20-25^{\circ} \mathrm{C}$ and light conditions were natural. In the experiment of decotylization, cotyledons were excised on the 8 th, 12 th, and 16 th days after germination. At respective growing stages, the growth of each organ was estimated. Photosynthesis of cotyledons and foliage leaves wasmeasured by an infra-red $\mathrm{CO}_{2}$ analizer from Hartmann \& Brawn (URAS-1) using an open circulation system(3). An excised single leaf was placed in the assimilation chamber (an elliptic cylinder: $11 \mathrm{~cm}$ in major axis, $7.5 \mathrm{~cm}$ in minor axis, and $0.5 \mathrm{~cm}$ in height) with its petiole immersed in water. The chamber containing a leaf was transfered into temperature controlled $\left(25^{\circ} \mathrm{C}\right)$ water and illuminated ( $30 \mathrm{klux}$ ) by incandescent lamps placed above a water filter $(10 \mathrm{~cm})$. The air flow rate was maintained at $0.51 / \mathrm{min}$.

\section{Results}

Experiment 1

Final yield of radishes was diminished by
Table 1. Effect of decotylization on the yield of thickened and foliage organs of radish plants. The seeds were sown on Sept. 11, 1973 and the cotyledon(s) were excised on Sept. 21 or Oct. 1. Plants were harvested on Nov. 29.

\begin{tabular}{c|c|c} 
& $\begin{array}{c}\text { Fresh weight } \\
\text { of thickened } \\
\text { organs } \\
(\mathrm{g})\end{array}$ & $\begin{array}{c}\text { Fresh weight } \\
\text { of foliage } \\
\text { organs } \\
\text { (g) }\end{array}$ \\
\hline \begin{tabular}{c|c} 
Decotylized at Sept. 21 \\
two cotyledons excised
\end{tabular} & $550 \pm 31^{* * *}$ & $480 \pm 25^{* * *}$ \\
one cotyledon excised & $610 \pm 20^{* * *}$ & $510 \pm 22^{* *}$ \\
Decotylized at Oct. 1 & & \\
two cotyledons excised & $700 \pm 30^{* *}$ & $530 \pm 25^{*}$ \\
one cotyledon excised & $790 \pm 30^{* *}$ & $540 \pm 18^{*}$ \\
Control & $810 \pm 19$ & $590 \pm 15$ \\
\hline
\end{tabular}

*** Significant from control at $0.1 \%$ level

** $1 \%$ level

* $5 \%$ level

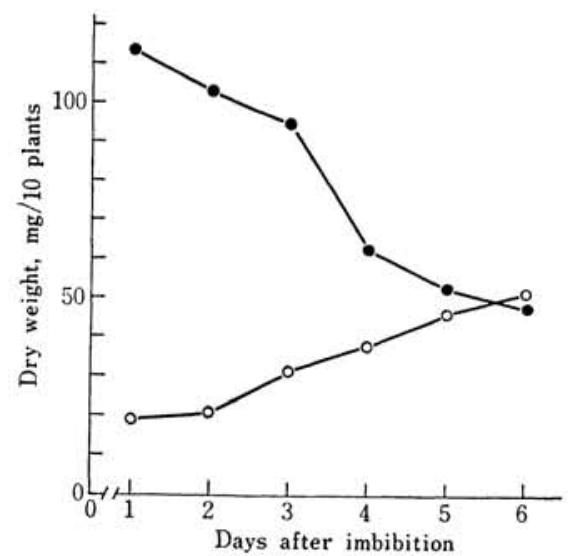

Fig. 1. Changes of dry weight of cotyledons(closed circles) and other organs (roots and hypocotyls, open circles) of radish seedlings grown in the dark at $25^{\circ} \mathrm{C}$.

decotylization (Table 1). The decrease in fresh weight of both thickened and foliage organs was larger in the two-cotyledon-excised plants than in the one-cotyledon-excised. The decrease was also larger in the plants decotylized on the 10 th day than in those decotylized on the 20 th day after sowing. Furthermore, the growth of foliage organs of plants was less affected by decotylization than that of thickened ones.

Experiment 2

Under the dark condition, the dry weight of cotyledons decreased during the 6 days of the experiment, whereas that of the other organs (roots and hypocotyls) increased (Fig. 1). Under the continuous ligh condition, the dry 


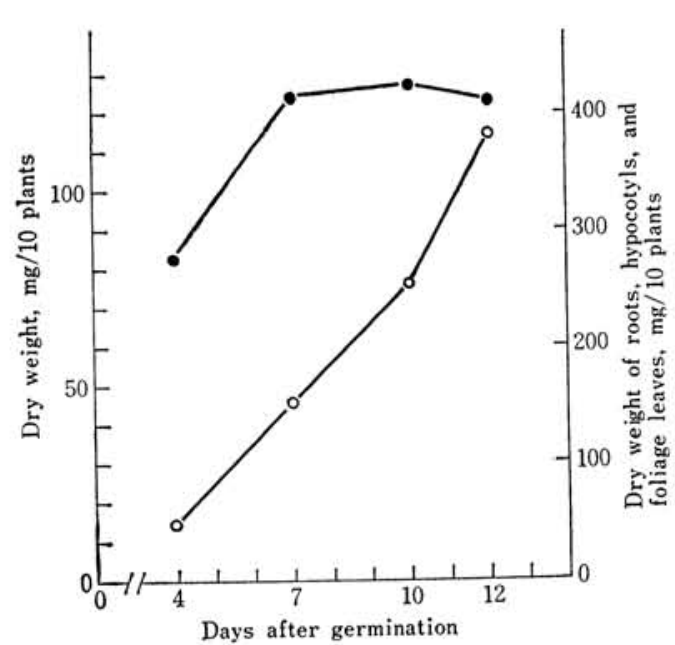

Fig. 2. Changes of dry weight of cotyledons (closed circles) and other organs (roots, hypocotls, and foliage leaves, open circles) of radish seedlings grown in continuous light at $20 \sim 25^{\circ} \mathrm{C}$.

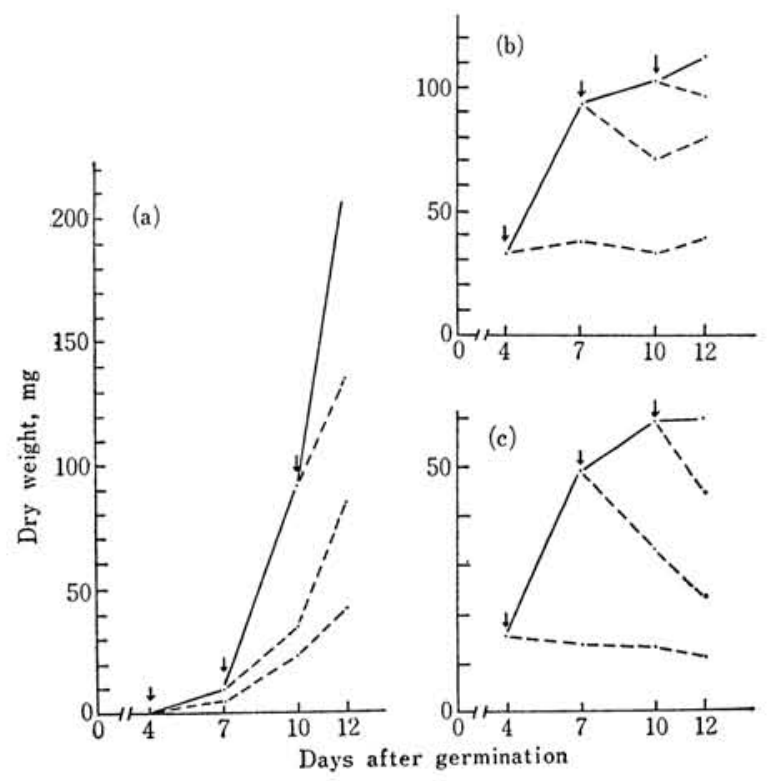

Fig. 3. Effect of decotylization on the change of dry weight of foliage leaves (a), hypocotyls (b), and roots (c) of radish seedling grown in continuous light at $20 \sim 25^{\circ} \mathrm{C}$. Arrows indicate the day when cotyledons were excised. Solid lines : control, broken lines : decotylized.
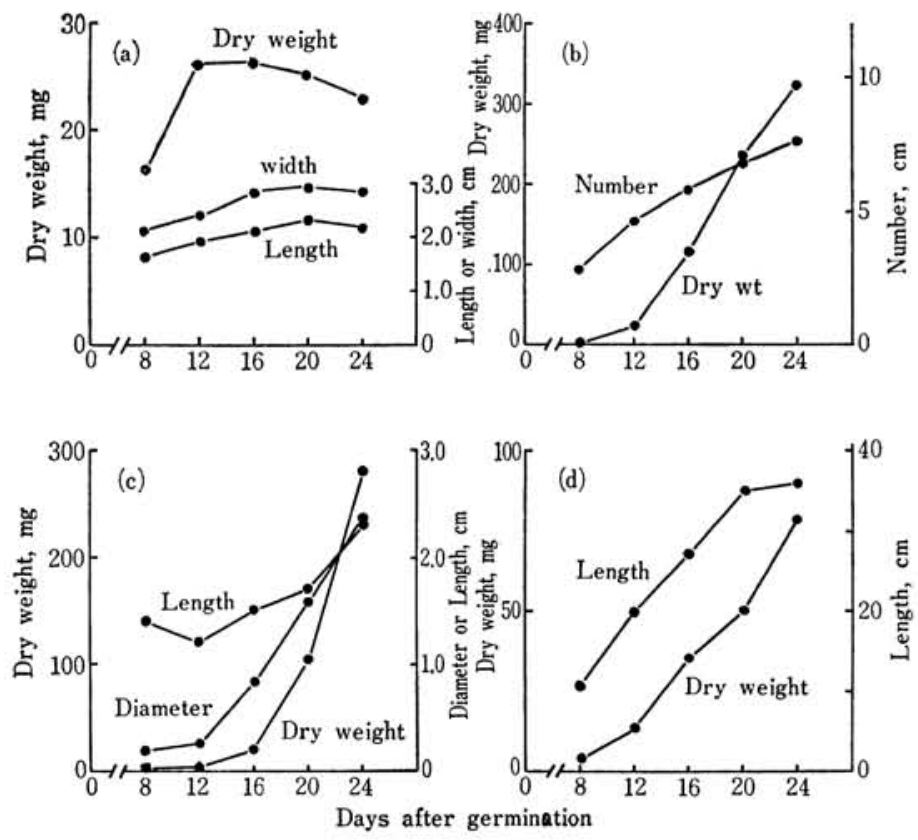

Fig. 4. (a) Changes of dry weight and size of cotyledons,

(b) Changes of dry weight and number of foliage leaves.

(c) Changes of dry weight, maximum diameter, and length of hypocotyls.

(d) Changes of dry weight and length of roots. 


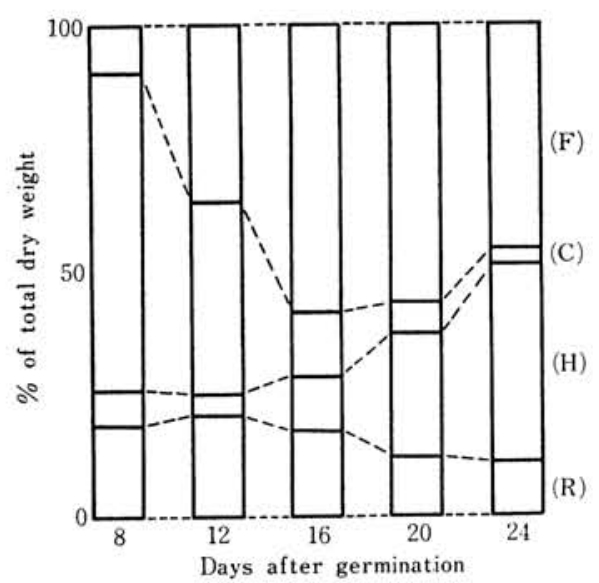

Fig. 5. Changes of relative dry weight of foliage leaves (F), cotyledons (C), hypocotyls (H), and roots (R) of radish plants. Relative dry weight of each organ was expressed as $\%$ of total dry weight.

weight of cotyledons reached the maximum value on the 10 th day and thereafter decreased. That of the other organs (roots, hypocotyls, and foliage leaves) increased (Fig. 2). The dry weight of roots or hypocotyls of the seedlings decotylized on the 4 th day maintained at almost constant levels or decreased slightly. However, a noticeable decrease in their dry weight, especially in the case of roots, was observed in the seedlings decotylized on the 7 th or 10 th day (Fig. 3). The dry weight of foliage leaves increased during the 12 days of the experiment in both control and decotylized seedlings. The growth of foliage leaves was, however, delayed by decotylization and the delay was conspicuous in radishes decotylized at earlier stages of growth.

\section{Experiment 3}

To study the role of cotyledons in radish growth in detail, Rapid Red cultivar was used. Plants were grown in a phytotoron for 24 days and the growth of each organ was estimated (Fig.4). Increase in the dry weight of foliage leaves began on the 12 th day and the number of foliage leaves increased rather constantly during 24 days of the experiment. The dry weight of cotyledons reached its maximum value between the $12-16$ th days and thereafter declined. Extension growth of cotyledons ceased between $16-20$ th days. Since the thickening growth of this cultivar occurs in its hypocotyl region, any increase in the dry weight of roots was not observed but that of hypocotyls occured after the 16 th day. Hypocotyls and roots elongated almost constantly.
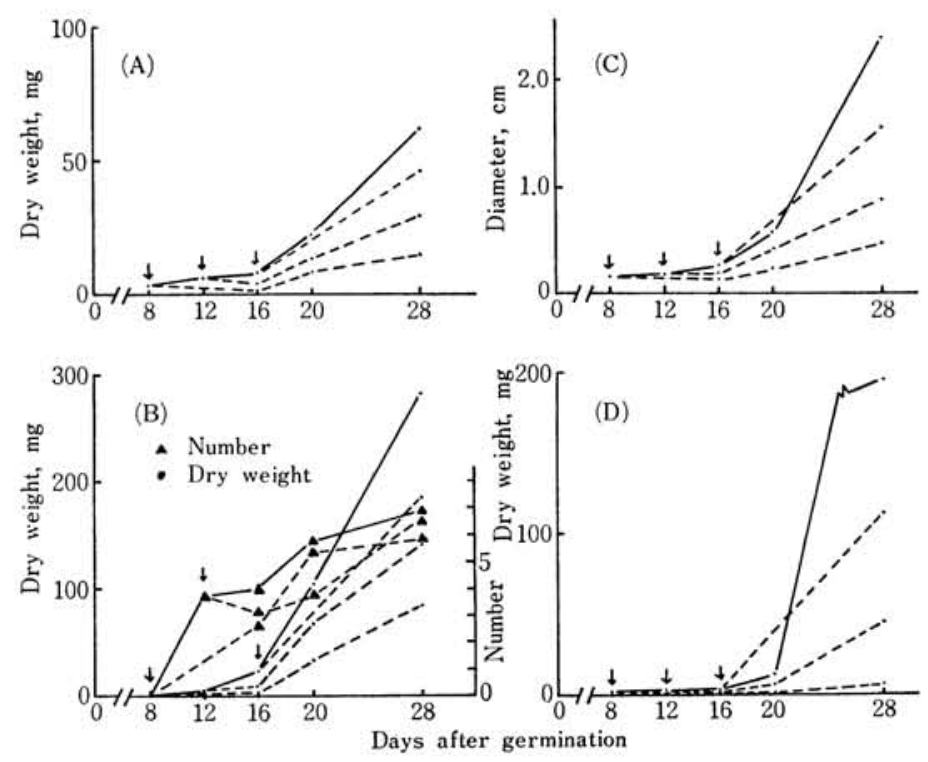

Fig. 6. Effect of decotylization on the growth of radish plants.

(A) : dry weight of roots. (B) : dry weight and of foliage leaves. (C) : maximum diameter of hypocotyls. (D): dry weight of hypocotyls. Arrows indicate the day when cotyledons were excised. Solid lines : control, broken lines: decotylized. 


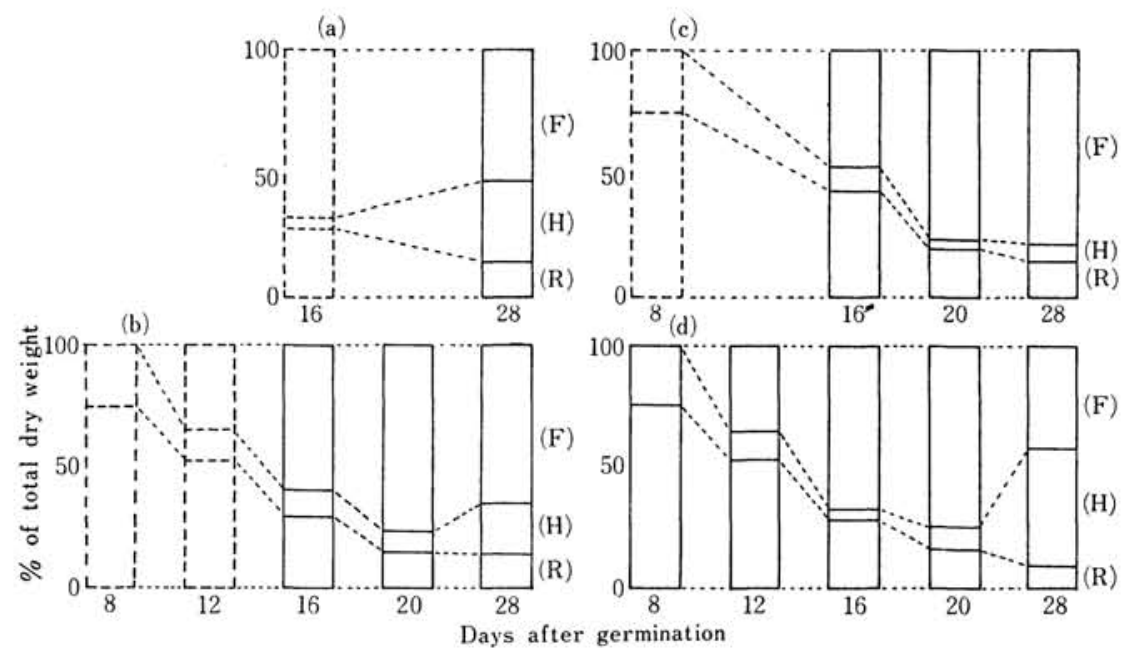

Fig. 7. Effect of decotylization on the relative dry weight of each organ of radish plants. Cotyledons were excised at 16 th day (a), 12 th day (b), and 8 th day (c). Control: (d). (F) : foliage leaves, (H): hypocotyls, (R) : roots.

Sloughing of the primary cortex was observed on the 12 th day. The growth of the radishes was summarized in Fig. 5. Although dry weight increased in every organ (Fig. 4), changes in the ratio of dry weight of organs to the total dry weight were observed. During 16 days after germination, although the changes in the ratio of roots and hypocotyls were not observed, that of foliage leaves increased and that of cotyledons decreased. Thereafter, the ratio of foliage leaves, cotyledons, and roots decreased, whereas that of hypocotyls increased.

Decotylization diminished radish growth and this phenomenon was observed in the growth of every organ (Fig. 6). The decrease in growth was larger in the plants decotylized earlier in the growing stage. The decotylization at an earlier stage of growth had a profound effect on delaying thickening growth of hypocotyls. This is consistent with the results obtained in Experiment 1 and 2. The final number of foliage leaves was not affected by decotylization but dry weight of foliage leaves decreased in decotylized plants. The growth of decotylized and control plants were summarized in Fig. 7. In the control plants, the ratio of foliage leaves reached a maximum value on the 20 th day and thereafter declined. This decline is due to a rapid increase in the hypocotyl part. On the other hand, the in-

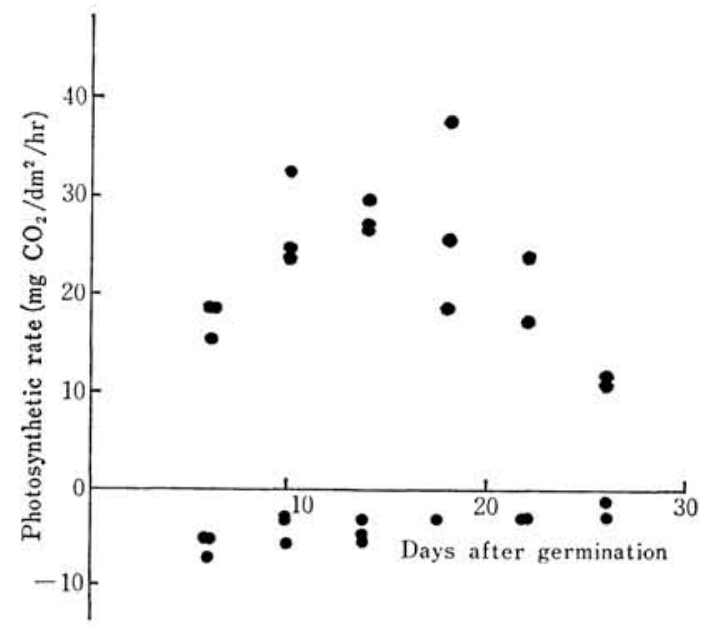

Fig. 8. Changes in photosynthesis and dark respiration of radish cotyledons. Details of experimental conditions are shown in the text.

crease in the ratio of foliage leaves was delayed in decotylized plants and this was conspicuous in the decotylized plants at earlier growing stages.

The changes in photosynthetic rate of cotyledons were shown in Fig. 8. During the 26 days of the experiment, the photosynthetic rate of cotyledons increased for 15 days and thereafter declined. This shows that the photosynthetic role played by cotyledons decreased after the 15 th day. Dark respiration 


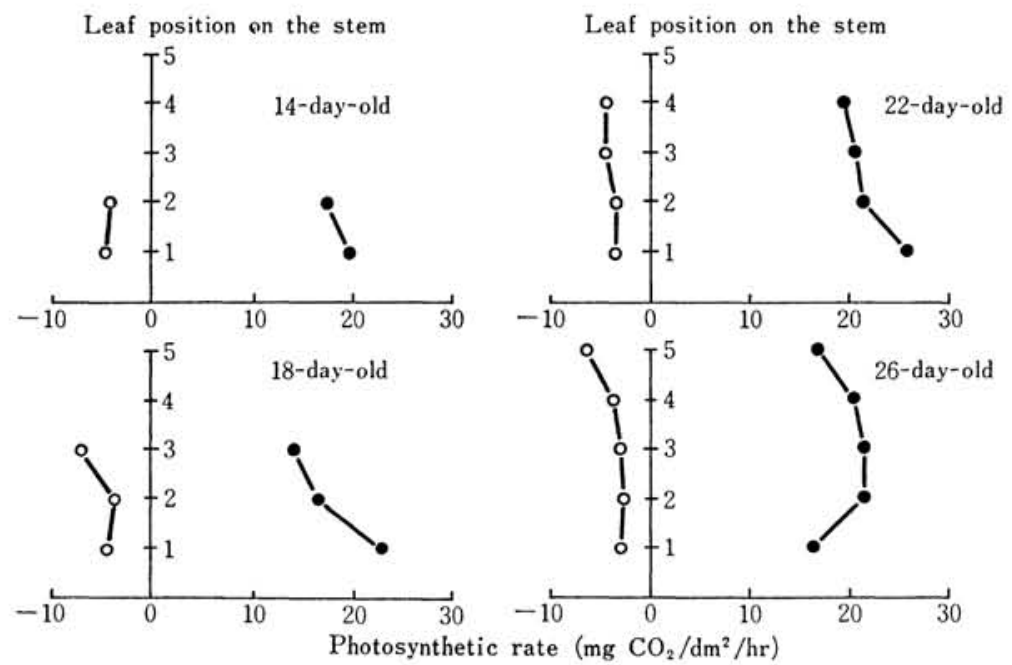

Fig. 9. Photosynthesis and dark respiration of foliage leaves at various growing stages. Details of experimental conditions are shown in the text.

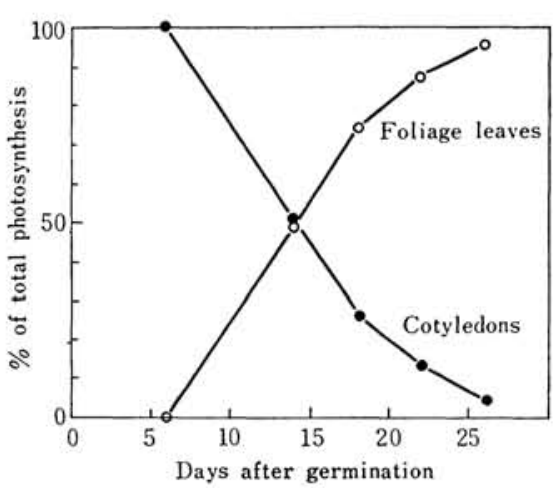

Fig. 10. Changes of relative photosynthesis of coty. ledons (closed circles) and foliage leaves (open circles) at various growing stages. These resits were obtained by calculating the values shown in Fig. 8 and 9.

of cotyledons declined with advanced aging. In foliage leaves, the photosynthetic rate of the first one reached the maximum value on the 22 nd day and then declined (Fig. 9). From this result, the senescence in photosynthesis of the first foliage leaf seems to begin at least on the 26 th day. And it may be generally accepted that there exists a sequential pattern of senescence in photosynthesis from under to upper levers. In dark respira tion of foliage leaves, its activity was higher in young ones than in old ones. The ratio of photosynthesis by cotyledons and that by foliage leaves to the total photosynthesis of a plant at the various growing stages was shown in Fig. 10. During the first 15 days of the experiment, the greater parts of the photosynthesis was carried out by cotyledons and thereafter photosynthesis by foliage leaves exceeded that of cotyledons.

\section{Discussion}

Since radish seeds are considered to be exalbuminous(5), it appears likely that the supply of nutritional materials to the actively growing regions during germination and during the early stage of growth is carried out by cotyledons, and thereafter foliage leaves exert these roles through photosynthetic action.

When seedlings of Risô Daikon were grown in the dark, a decrease in dry weight of cotyledons and an increase in that of the other organs were observed (Fig. 1). These results appear to be due to the supply of nutritional materials to the growing region, especially to hypocotyls stimulated in elongation growth in the dark. And these rusults may also suggest the catabolic nature of cotyledons and the anabolic nature of the other organs as demonstrated by Oот et al. with Vigna sequipedalis(11). Under the light condition, however, an increase of dry weight of both cotyledons and the other organs was observed (Fig. 2). This increase in cotyledons grown in the light apparently differed from 
the result obtained in the dark (Fig. 1), and may be considered as a result of their photosynthetic action (Fig. 8). Furthermore, the observation that the dry weight of both hypocotyls and roots decreased, whereas that of foliage leaves increased in the plants decotylized at the 7 th and the 10 th day (Fig. 3) will be interpreted as the result of retranslocation of dry matters from both hypocotyls and roots to foliage leaves, and this suggests that the supply of dry matters to foliage leaves, hypocotyls, and roots was carried out by cotyledons in intact plants grown even in the light. In other words, the cotyledon is the source and the other organs are the sink. And, since it is considered that hypocotyls and roots are the source and foliage leaves are the sink in decotylized plants (Fig. 3), foliage leaves may be regarded as the strongest sink. Therefore, these results indicate that there are at least two roles of cotyledons in radish growth: the role of a strage organ and the role of a photosynthetic organ.

In Rapid Red cultivar, the growth of each organ was estimated. From the results shown in Fig. 5, the growth phase could be divided into two: Phase 1 and Phase 2. In Phase 1, although every organ increased in dry weight (Fig. 4), the ratio of cotyledons decreased and that of foliage leaves increased. Furthermore, dry weight and photosynthetic activity of cotyledons increased during this phase and attained their maximum, values at the end of this phase (Fig. 4 and 5). On the other hand, increase in dry weight and photosynthetic activity of foliage leaves began at nearly the end of Phase 1 and photosynthesis by foliage leaves exceeded that by cotyledons in Phase 2. In Phase 2, foliage leaves appear to play important roles in radish growth.

Although two cultivars used in this experiment, i. e. Risô Daikon and Rapid Red, are different in many respects, it may be admissible to consider that the role of cotyledons in growth is not essentially different between two cultivars. Therefore, decotylization in the early stages of growth caused a depression in the growth of foliage leaves because of the loss of strage and the loss of one of the photosynthetic organs from which they are supplied nutritional materials for their growth. As the increase in thickening growth may be caused by a sufficient supply of photosynthetic products from foliage leaves, the decrease in the growth of foliage leaves may cause a decrease of growth of thickened organs. Thus it is concluded that the decrease in final yield by decotylization is due to the decrease in the growth of foliage leaves.

Several workers have reported the role of cotyledons in the regulation of hypocotyl elongation $(1,6,7)$. In respect to the mechanism of the thickening growth in radishes, Loomis et al $(8,12,14,15)$ suggested the possibility that auxins and cytokinins transported downward regulate thickening through the activation of cambial activity. But the cites of synthesis of these growth hormones are still unknown. However, since sloughing of the primary cortex which is an indicator of the beginning of active thickening growth was observed in an early stage of growth when cotyledons play major roles in radish growth, it may be possible to consider the cotyledons as one of the cites. Further studies must be done to clarify these issues.

\section{Acknowlegement}

I wish to express my thanks to Mr. K. Sakakibara for his technical assistance throughout this work. I also appreciate the suggestion and criticism of members of our laboratory, Dr. A. Furukawa, Dr. S. Kako, Assistant Prof. of Nagoya University, Dr. H. Totikata, Prof. of Nagoya University, and Dr. T. Takano, Prof. of Meijo University.

\section{Literature cited}

1. BLACK, M., and J.E. Schuttle. 1974. Photocontrol of hypocotyl extension in Cucumis sativus L. Planta. $117: 57-66$.

2. FRIES, N. 1954. Chemical factors controlling the growth of the decotylized pea seedlings. Symb. Bot. Upsal. XIII : 1 .

3. FURUKaWA, A., and M. Kadota. 1975. Effect of ozone on photosynthesis and respiration in poplar leaves. Environ. Control. in Biol. 13: $1-7$.

4. Goto, N., and Y. ESASHI. 1973. Diffusible and extractable gibberellin in bean cotyledons in relation to dwarfism. Physiol. Plant. 28 : $480-489$.

5. HAYWARD, H. E. 1938. The structure of economic plants. pp. 283-308. The Macmillan 
company.

6. KAMISAKA, S. 1973. Requirement of cotyledons for gibberellic acid-induced hypocotyl elongation in lettuce seedlings. Isolation of the cotyledon factor active in enhancing the effect of gibberellic acid. Plant \& Cell Physiol. $14: 747-755$.

7. Katsumi, M., W. K. Purves, B. O. Phinney and J. KATO. 1965. The role of cotyledons in gibberellin- and auxin-induced elongation of the cucumber hypocotyl. Physiol. Plant. 18 : $550-556$.

8. LOOMIS, R. S., and J. G. TORREY. 1964. Chemical control of vascular cambium initiation in isolated radish roots. Proc. N. A. S. $52: 3-11$.

9. MOORE, T. C. 1964. Effects of cotyledon excision on the flowering of five varieties of Pisum sativum. Plant Physiol. 39: 924-929.

10. 1965. Effects of gibberellin on the growth and flowering of intact and decotylized dwarf peas. Nature. $206: 205-206$.

11. OOTA, Y., R. FUJII, and S. OSAWA. 1953. Changes in chemical constituents during the germination stage of a bean, Vigna sequipedalis. J. Biochem. $40: 649-661$.

12. SHUE-LOCK LAM, and A.C. LEOPOLD. 1966. Role of leaves in phototropism. Plant Physiol. $41: 847-851$.

13. TORREY, J. G., and R. S. LOOMIS. 1967. Ontogenetic studies of vascular cambium formation in excised roots of Raphanus sativus L. Phytomorphology. $17: 401-409$.

14. -, and 1967. Auxin-cytokinin control of secondary vascular tissue formation in isolated roots of Raphanus. Amer. J. Bot. 54 : 1098-1106.

15. RADIN, J. W., and R. S. Loomis. 1971. Changes in the cytokinins of radish roots during maturation. Physiol. Plant. 25 : 240-244.

16. SHININGER, T. L. 1972. Gibberellin substitution for the requirement of the cotyledons in stem elongation. in Pisum sativum seedlings. Plant Physiol. 49 : 341-344.

17. YataZawa, M., and S. Yoshida. 1965. The role of cotyledon on root nodule formation in soy bean seedlings. J. Soil and Manure, Japan $36: 263-267$. (in Japanese).

\title{
ダイコンの生長と光合成における子葉の役割
}

\author{
鈴木茂 敏 \\ (名古屋大学農学部)
}

\begin{abstract}
摘 要
ダイコンの生育初期における子葉切除処理はその後の 生長と収量を減少させることが観察された. そこで, ダ イコンの生長における子葉の役割を明らかにする目的で 本研究を行なった.

1. 注場で育てられた理想ダイコンにおいて，子葉切 除処理による収量の低下が観察された，子葉切除の影瑤 は，早期の処理区および子葉 2 枚切除区において，より 顥著に現われた。

2. 暗黑条件のもとでは，理想ダイコン幼植物の子葉 の乾物は経時的に減少し, その他の器官では增加した. いっぽう, 明条件下においてはどの器官の乾物も增加し

た. また, 子葉切除処理により, 根部と下はい軸部の乾 物の減少が観察されたが本葉ではみられなかった.

3. ハッカダイコン（ラピッド・レッド）の生育期は 大きく 2 期に分けられ, 第 1 期では子葉は主要な眝藏器 官および光合成器官として働き，とくに本葉の生長に重 要な役割をむっと考えられた. 第 2 期では, 子葉にかわ って本葉が乾物生産において主要な役割をもち，とくに 下はい軸の肥大生長に関係するものと考えられた.

以上の結果より, 子葉切除によるダイコンの生長扰よ び収量の低下は, 子葉切除処理によっておこる本葉の生 長の低下によるものと考えられる.
\end{abstract}

